Review

\title{
Interaction of Polyphenols as Antioxidant and Anti-Inflammatory Compounds in Brain-Liver-Gut Axis
}

\author{
Amritpal Singh, Yu Fung Yau, Kin Sum Leung, Hani El-Nezami $(\mathbb{1})$ and Jetty Chung-Yung Lee *(1) \\ School of Biological Sciences, The University of Hong Kong, Pokfulam Road, Hong Kong, China; \\ amritpal@connect.hku.hk (A.S.); hyfyau@connect.hku.hk (Y.F.Y.); sam612@connect.hku.hk (K.S.L.); \\ elnezami@hku.hk (H.E.-N.) \\ * Correspondence: jettylee@hku.hk; Tel.: +852-2299-0318
}

Received: 2 July 2020; Accepted: 24 July 2020; Published: 26 July 2020

\begin{abstract}
Oxidative stress plays an important role in the onset as well as the progression of inflammation. Without proper intervention, acute inflammation could progress to chronic inflammation, resulting in the development of inflammatory diseases. Antioxidants, such as polyphenols, have been known to possess anti-oxidative properties which promote redox homeostasis. This has encouraged research on polyphenols as potential therapeutics for inflammation through anti-oxidative and anti-inflammatory pathways. In this review, the ability of polyphenols to modulate the activation of major pathways of inflammation and oxidative stress, and their potential to regulate the activity of immune cells are examined. In addition, in this review, special emphasis has been placed on the effects of polyphenols on inflammation in the brain-liver-gut axis. The data derived from in vitro cell studies, animal models and human intervention studies are discussed.
\end{abstract}

Keywords: oxidative stress; inflammation; polyphenols; antioxidant

\section{Introduction}

One of the main innate responses of the immune system is inflammation, which is an important non-specific response to any kind of injury and infection, such as physical wounds, toxins and tissue damage. It is a crucial response to the alteration of tissue integrity, to initiate healing and restore tissue homeostasis [1]. Several types of white blood cells, such as neutrophils and macrophages, and cytokines are involved in the inflammatory process. Cytokines play an enormous part in the inflammatory response and are mainly produced by helper $\mathrm{T}$ cells and macrophages [2]. They can be classified into pro-inflammatory cytokines, such as interleukin (IL)- $1 \beta$ and the tumor necrosis factor (TNF)- $\alpha$, and anti-inflammatory cytokines, such as IL-4 and IL-10 [2]. The regulation and balance between the two types of cytokines is crucial for the immune system. An overproduction of pro-inflammatory cytokines could lead to autoimmune diseases and chronic inflammatory diseases, thus highlighting the need for anti-inflammatory cytokines to prevent chronic inflammatory conditions [2].

The inflammatory response is a multi-stage process which involves a triggering system, a sensor mechanism, signal transmission and the production of inflammatory mediators [1]. The inflammatory response could be triggered by various danger signals, which could be from exogenous, such as invasion by microorganisms, or endogenous sources, such as tissue damage. The exogenous and endogenous signaling molecules are termed pathogen-associated molecular patterns (PAMPs) and damage-associated molecular patterns (DAMPs) respectively [1]. PAMPs and DAMPs are sensed by a variety of pattern recognition receptors (PRRs) which include Toll-like receptors (TLRs), nucleotide-binding oligomerization domain (NOD)-like receptors (NLRs), C-type lectins and receptors 
for advanced glycation end-products (RAGE) [1]. The activation of PRR triggers intracellular signaling cascades, including kinases, such as mitogen-activated protein kinases (MAPKs), adaptors, the myeloid differentiation primary response protein 88 (MyD88), and transcription factors, such as the nuclear factor kappa B (NF- $\mathrm{kB})$. Furthermore, the activation of NLR could trigger cytokine maturation, which are key to inflammation development, through inflammasomes. For instance, activated NLRP3 are associated to the adaptor protein ASC (apoptosis associated speck-like containing a CARD domain) and caspase- 1 to form inflammasome, which promotes the conversion of pro-IL- $1 \beta$ and pro-IL-18 to mature IL-1 $\beta$ and IL-18, respectively [1]. Upon DAMP binding, TLR interacts with MyD88 which activates downstream signaling, resulting in NF- $\mathrm{kB}$ and activator protein-1 (AP-1) activation [3]. The signaling pathways mentioned above upregulate the expression of inflammatory mediators like cytokines for inflammation development.

It has been long known that significant oxidative stress could cause cellular damage and modification of genes, which triggers the inflammatory signaling cascade for the onset of inflammation in various inflammatory diseases [4]. As part of the inflammatory response, large amounts of reactive oxygen species (ROS) are generated, which could further promote oxidative stress and chronic inflammation if produced for lengthened periods [1,4]. Besides, several studies have pointed out that oxidants have a significant part in the activation of TLRs $[5,6]$. The studies have shown that the translocation of TLR4 to the cell membrane was upregulated after exposure to oxidants $[5,6]$. This enhances the responsiveness of cells to a danger signal for the onset of pro-inflammatory signaling pathways. One of the most discussed pathways in inflammation is the NF- $\kappa B$ pathway. It is a key regulator of inflammation due to its sensitivity to ROS. The activation of NF-KB could result from two pathways, the canonical and alternative pathways [1,7]. In both pathways, NF- $\mathrm{kB}$ is freed from its inhibitor, IкB, resulting in NF- $\mathrm{kB}$ translocation to the nucleus for the expression of target genes [1].

Under oxidative stress, the expression of antioxidant genes is upregulated, which is modulated by the nuclear factor erythroid 2-related factor 2 (Nrf2) [8]. Nrf2 activation is induced by ROS by the removal of its inhibitor, Kelch-like erythroid CNC homolog-associated protein 1 (Keap1), allowing the translocation of Nrf2 to the nucleus for the expression of genes involved in the antioxidant response [8].

As mentioned earlier, significant oxidative stress results in the propagation of inflammation, which illustrates the importance of redox balance in the resolution, and prevention of inflammation. Redox homeostasis is maintained by antioxidants, which could be from endogenous or exogenous (natural or synthetic) sources. The endogenous sources of antioxidants consist of enzymes such as glutathione peroxidase (GPx), superoxide dismutase (SOD) and catalase (CAT) [4]. Minerals such as zinc, selenium and copper are essential for the activation of the antioxidant enzymes as they are co-factors for these enzymes [9]. The natural exogenous antioxidants include ascorbic acid (vitamin C), $\alpha$-tocopherol (vitamin E), carotenoids and flavonoids [4,9]. Antioxidants can scavenge free radicals which terminates the chain reaction of oxidation. Besides, they could prevent the initiation of a chain reaction by binding to transition metal ions that catalyze ROS generation $[4,9]$. As a result, antioxidants are able to reduce oxidative stress.

Polyphenols have been long known to be potent antioxidants. Polyphenols are found in various types of food, including fruits and vegetables, and can be classified into flavonoids and non-flavonoids [10]. Examples of flavonoids include anthocyanins, epigallocatechin gallate (EGCG) and curcumin, while an example of a non-flavonoid is resveratrol (RES) [10-12]. Because of their effects on oxidative stress, researchers have studied the effects of polyphenols in conditions with common underlying factors such as oxidative stress and inflammation. Polyphenols have been studied as potential anti-inflammatory agents in various inflammatory diseases, such as non-alcoholic fatty liver disease (NAFLD), inflammatory bowel disease and neurodegenerative diseases [10-12]. As illustrated in Figure 1, it is hypothesized that polyphenols would modulate the inflammatory signaling pathway via an antioxidant-based mechanism. It is expected that polyphenols would reduce oxidative stress, which would inhibit signal transduction for the production of pro-inflammatory mediators. The aim of this review will be to discuss the effects of polyphenol intervention in experimental and clinical 
settings on inflammation in specific organs, namely the brain, liver and gut, with reference to their antioxidant and anti-inflammatory properties.

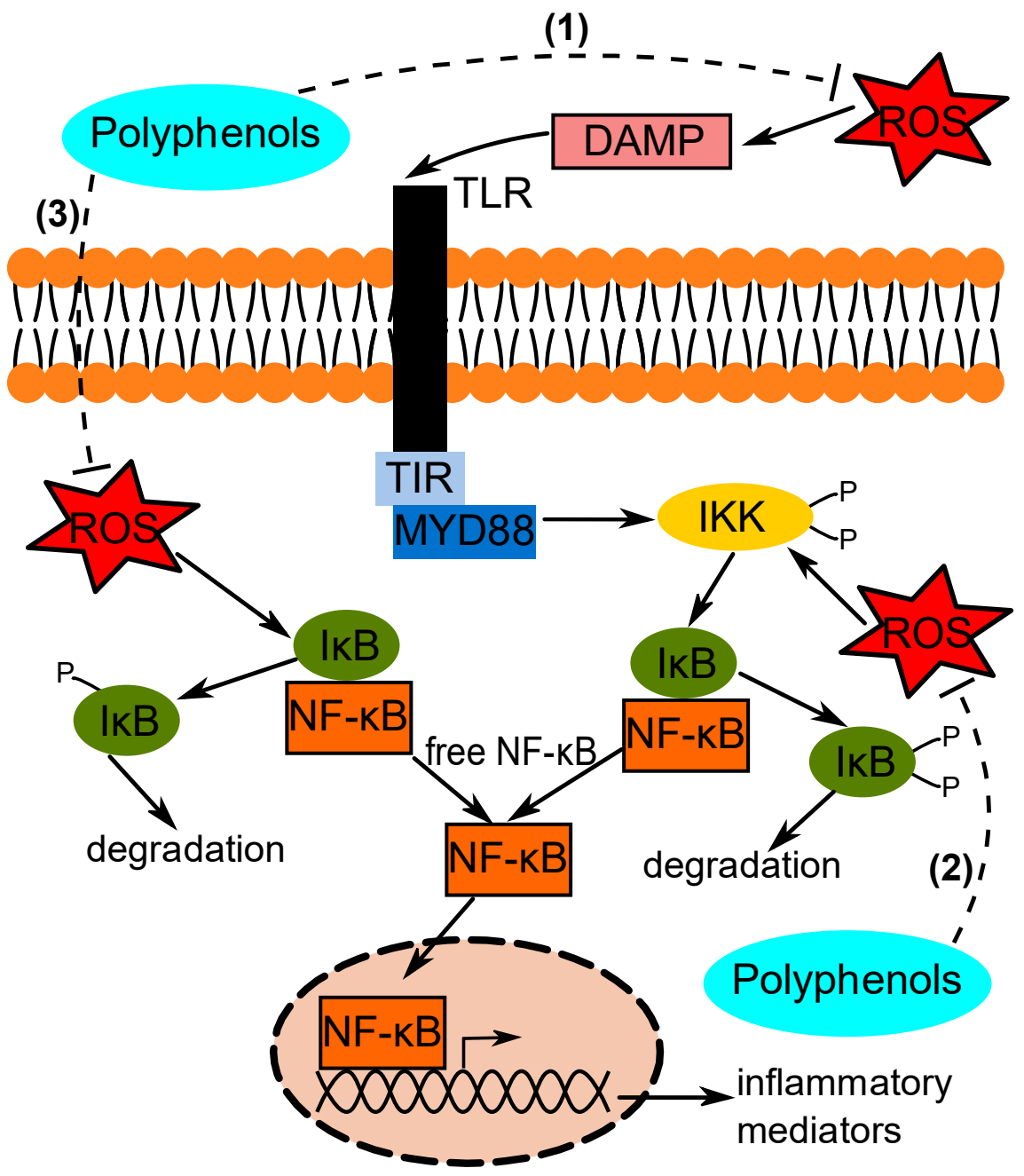

Figure 1. Potential mechanism of action of polyphenols in inflammation inhibition. Polyphenols may target the reactive oxygen species (ROS) to reduce oxidative stress. (1) ROS reduction could reduce the amount of damage-associated molecular patterns (DAMPs); (2) ROS reduction could also arrest

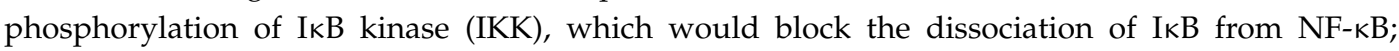
(3) ROS could directly phosphorylate IKB, which could be prevented by polyphenols. These pathways would inhibit nuclear translocation of NF- $\mathrm{KB}$.

\section{Polyphenol Intervention in Brain Inflammation}

Some of the most common brain disorders include neurodegenerative diseases such as Alzheimer's disease and Parkinson's disease [10-13]. Despite the exact causes of these diseases being unclear, these disorders have been linked to common underlying factors which are high levels of oxidative stress and inflammation [10-13]. Due to these reasons, the use of antioxidants as potential therapeutic agents has emerged. For instance, the effects of polyphenols have been studied on factors that are involved in disease progression. The findings of these studies in the last 15 years (2004-2019) are summarized in Table 1. 
Table 1. Summary of the effects of polyphenols on brain inflammation in the last 15 years (2004-2019).

\begin{tabular}{|c|c|c|c|}
\hline Model of Study & Agent & Effects & Reference \\
\hline \multicolumn{4}{|l|}{ In vitro } \\
\hline Human neuroblastoma SH-SY5Y cells (oxysterol induced) & Quercetin & $\downarrow$ TLR4 signaling & [14] \\
\hline Human PBMC (oxLDL-induced) & Quercetin & $\downarrow$ TLR2 and TLR4 expressions, NF- $\mathrm{kB}$ activation, inflammatory enzymes activity & [15] \\
\hline Human astrocytes (LPS-induced) & Anthocyanins & $\begin{array}{c}\downarrow \text { IL-6 secretion (low LPS and anthocyanin dose); } \\
\uparrow \text { IL-6 secretion (high anthocyanin dose in LPS absence) }\end{array}$ & [16] \\
\hline Mouse BV2 microglial cells (LPS-induced) & Blueberry extract & $\downarrow N O$ and TNF- $\alpha$ release, iNOS and COX-2 expressions, NF- $\kappa B$ nuclear translocation & [17-19] \\
\hline Mouse BV2 microglial cells (LPS-induced) & Anthocyanins & $\begin{array}{l}\downarrow \text { NO, PGE2, TNF- } \alpha \text { and IL-1 } \beta \text { release, iNOS and COX-2 expressions, } \\
\text { NF- } k B \text { nuclear translocation }\end{array}$ & {$[20,21]$} \\
\hline Mouse microglial cells (LPS/IFN- $\gamma$-induced) & Anthocyanins & $\downarrow N O$ and TNF- $\alpha$ release, iNOS expression & [22] \\
\hline Rat HAPI microglial cells (LPS-induced) & Tart cherry extract & $\downarrow$ NO and TNF- $\alpha$ release, COX-2 expression; $\leftrightarrow$ iNOS expression & [23] \\
\hline Rat astrocytes (LPS-induced) & Lingonberry extract & $\downarrow$ ROS production & [24] \\
\hline \multicolumn{4}{|l|}{ Animal } \\
\hline Mouse model (PD) & GSSE & $\downarrow$ ROS production, inflammatory markers & [25] \\
\hline $\begin{array}{c}\text { Mouse model (LPS and A } \beta \text {-induced microglia } \\
\text { neuroinflammation) }\end{array}$ & RES & $\downarrow$ TLR4, NF- $\mathrm{KB}$ and cytokine secretion & [26] \\
\hline $\begin{array}{c}\text { Mouse model (LPS-impaired adult hippocampal } \\
\text { neurogenesis) }\end{array}$ & EGCG & $\downarrow$ TLR4 signaling & [27] \\
\hline Mouse model (LPS-treated) & Anthocyanins & $\downarrow N F-k B, T N F-\alpha$, and IL- $1 \beta$ levels & [28] \\
\hline Mouse model (LPS-treated) & PSPC & $\downarrow$ TNF- $\alpha$, IL- 6 and IL- $1 \beta$ overproduction, NF-kB activation & [29] \\
\hline Mouse model (LPS-treated) & Anthocyanins & $\downarrow$ ROS production, NF-kB activation, TNF- $\alpha$, and IL-1 $\beta$ levels & [30] \\
\hline Mouse model (LPS-treated) & Anthocyanins & $\downarrow$ TNF- $\alpha$, and IL-1 $\beta$ increase; $\uparrow$ IL-10 expression & [31] \\
\hline Mouse model (high-fat diet) & PSPC & $\begin{array}{l}\downarrow \text { iNOS, COX-2, TNF- } \alpha, \text { IL- } 1 \beta \text { and IL- } 6 \text { expressions, p38 MAPK and NF-kB activation; } \\
\uparrow \text { IL-10 levels }\end{array}$ & [32] \\
\hline Rat model (MCAO/R) & Anthocyanins & $\downarrow$ TNF- $\alpha$, IL- 6 and IL-1 $\beta$ levels, NF-kB and NLRP3 expressions & [33] \\
\hline \multicolumn{4}{|l|}{ Human } \\
\hline Subjects with $\mathrm{AD}$ & RES & $\downarrow$ plasma pro-inflammatory markers & [34] \\
\hline
\end{tabular}

$\uparrow$ : increase; $\downarrow$ : decrease; $\leftrightarrow$ : insignificant change; A $\beta$ : beta-amyloid; AD: Alzheimer's disease; COX: cyclooxygenase; EGCG: epigallocatechin gallate; GSSE: grape seed and skin extract; IFN- $\gamma$ : interferon gamma; IL: interleukin; iNOS: inducible nitric oxide synthase; LDL: low-density lipoprotein; LPS: lipopolysaccharide; MAPK: mitogen-activated protein kinase; MCAO/R: middle cerebral artery occlusion/reperfusion; NF- $\mathrm{kB}$ : nuclear factor kappa B; NLRP: NOD-like receptor protein; NO: nitric oxide; ox: oxidized; PBMC: peripheral blood mononuclear cell; PD: Parkinson's disease; PGE2: prostaglandin E2; PSPC: purple sweet potato color; RES: resveratrol; ROS: reactive oxygen species; TLR: toll-like receptor; TNF- $\alpha$ : tumor necrosis factor alpha. 


\subsection{In Vitro Models of Polyphenol Treatment in Brain Inflammation}

Among several in vitro studies, one group reported the inhibition of TLR4 signaling in cells treated with quercetin [14]. Besides, the expressions of TLR2 and TLR4 being reduced by quercetin, it further decreased the production of pro-inflammatory cytokines [15]. Furthermore, quercetin has been shown to attenuate the activity of inflammatory enzymes, including inducible nitric oxide synthase (iNOS) and cyclooxygenase (COX) [15]. In studies that tested anthocyanin-rich extracts in response to lipopolysaccharide (LPS) stimulation, a significant reduction in the production of TNF- $\alpha$ and IL-1 $\beta$, and expressions of iNOS and COX-2 was reported [17-21]. A study on rat highly aggressively proliferating immortalized (HAPI) cells demonstrated similar results, but with no significant effect on iNOS expression [23]. In mouse microglial cells, anthocyanins reduced NO and TNF- $\alpha$ release and iNOS expression [22]. The reduced levels of pro-inflammatory mediators have been attributed by the modulation of inflammatory signaling pathways, since decreased levels of active p38 MAPK and NF- $\mathrm{B}$ have been observed [17-21]. Besides microglial cells, anthocyanins testing on astrocytes has also revealed similar findings. For instance, rat astrocytes treated with anthocyanin-rich lingonberry extract lowered ROS production, suggesting an anti-oxidative mechanism [24]. In a human astrocyte study, the secretion of IL-6 was reduced at low doses of LPS and anthocyanins [16]. However, in the absence of LPS, IL-6 secretion increased when treated with high concentration of anthocyanin, suggesting antioxidant toxicity with a single compound supplementation [16]. Some studies have highlighted that the synergistic effects of mixed polyphenols provided better outcomes than single compound supplementation. Moreover, it was reported that the anti-inflammatory effects were more significant when the cells were treated with high concentrations of anthocyanins.

\subsection{In Vivo Models of Polyphenol Treatment in Brain Inflammation}

In a mouse model of Parkinson's disease, the neuroprotective effects of grape seed and skin extract (GSSE), which is a mixture of polyphenolic compounds that is mostly comprised of flavonoids namely catechins, gallic acid, vanillin and 2,5-dihydroxybenzoic acid, were studied [25]. A reduction in ROS production, nuclear translocation of NF- $\mathrm{KB}$ p65 subunit and loss of SOD was observed [25]. RES inhibited TLR4, NF- $\mathrm{BB}$ and cytokine secretion in LPS and $\beta$-amyloid (A $\beta$ )-mediated microglia neuroinflammation [26]. EGCG could attenuate TLR4 signaling in LPS-impaired adult hippocampal neurogenesis [27]. In addition, findings from anthocyanin treatment in LPS-induced mouse models have reported a decrease in several markers of oxidative stress and pro-inflammation. For example, levels of pro-inflammatory cytokines, such as TNF- $\alpha$, IL-6 and IL-1 $\beta$, were attenuated [28-31]. Furthermore, NF- $\kappa$ B activation was inhibited [28-30]. In one study, the expression of anti-inflammatory cytokines, such as IL-10, increased when the mice were pre-treated with anthocyanins [31]. Purple sweet potato extract showed anti-inflammatory effects in mice fed a high-fat diet (HFD), in which the expressions of iNOS, COX-2, TNF- $\alpha$, IL-6 and IL-1 $\beta$ attenuated, and the levels of IL-10 increased [32]. Furthermore, the activation of p38 MAPK and NF- $\mathrm{kB}$ was inhibited [32]. Similarly, anthocyanin treatment in a rat middle cerebral artery occlusion/reperfusion (MCAO/R) model demonstrated decreased expressions of NF- $\kappa$ B, NLRP3 and pro-inflammatory cytokines [33].

For human studies in relation to polyphenol intervention, a few have been conducted. One study on the administration of RES was shown to decrease neuroinflammation in patients with Alzheimer's disease [34]. The findings from in vitro and in vivo animal studies have demonstrated the benefits of polyphenols on brain inflammation. However, more human studies are required to validate the beneficial effects of polyphenols in brain-related inflammation.

\section{Polyphenol Intervention in Liver Inflammation}

One of most common liver diseases is NAFLD [35,36]. This disease could further progress to non-alcoholic steatohepatitis (NASH), and can eventually develop into hepatocellular carcinoma [35]. Similar to brain inflammation, the effects of polyphenol interventions in liver inflammation have been 
extensively researched. The findings of the effects of polyphenols on liver health in the last 15 years (2004-2019) are summarized in Table 2.

Table 2. Summary of the effects of polyphenols on liver inflammation in the last 15 years (2004-2019).

\begin{tabular}{|c|c|c|c|}
\hline Model of Study & Agent & Effects & Reference \\
\hline \multicolumn{4}{|l|}{ In vitro } \\
\hline $\begin{array}{l}\text { Hepatic stellate cells } \\
\text { (glucose-induced) }\end{array}$ & Curcumin & $\begin{array}{l}\downarrow \text { ROS production; } \uparrow \text { GCL activity, } \\
\text { GSH level }\end{array}$ & [37] \\
\hline $\begin{array}{l}\text { Human HepG2 cells } \\
\text { (fatty acid-induced) }\end{array}$ & Theaflavins & $\downarrow$ ROS production & [38] \\
\hline $\begin{array}{l}\text { Human HepG2 cells } \\
\text { (glucose-induced) }\end{array}$ & C3G & $\begin{array}{l}\downarrow \text { ROS production; } \uparrow \text { GCL activity, } \\
\text { GSH level }\end{array}$ & [39] \\
\hline $\begin{array}{l}\text { Mouse macrophage cells } \\
\text { (palmitic acid-induced) }\end{array}$ & Rutin & $\begin{array}{l}\downarrow \text { ROS production, } M C P-1, T N F-\alpha, I L-6 \text {, } \\
I F N-\gamma, I L-1 \beta \text { genes expressions }\end{array}$ & {$[40]$} \\
\hline \multicolumn{4}{|l|}{ Animal } \\
\hline $\begin{array}{l}\text { Mouse model } \\
\text { (Western diet) }\end{array}$ & Quercetin & $\begin{array}{c}\downarrow \text { TBARS, TG and TNF- } \alpha \text { levels; } \\
\uparrow \text { GPx and CAT levels }\end{array}$ & {$[41]$} \\
\hline Mouse model (MCD) & Quercetin & $\begin{array}{l}\downarrow \text { TLR4 protein concentration, TNF- } \alpha \text {, IL-6 } \\
\text { and COX-2 mRNA expressions }\end{array}$ & {$[42]$} \\
\hline Mouse model (HFD) & Rutin & $\downarrow T N F-\alpha$ and Mcp 1 gene expressions & [40] \\
\hline Mouse model (HFD) & Troxerutin & $\downarrow$ ROS levels; $\uparrow$ GPx, GSH and SOD levels & [43] \\
\hline $\begin{array}{l}\text { Mouse model } \\
(\mathrm{MCDHFD})\end{array}$ & Theaflavins & $\begin{array}{l}\downarrow \text { TBARS level, ROS production, } \\
\text { TNF- } \alpha \text { expressions }\end{array}$ & {$[44]$} \\
\hline Mouse model (HFD) & Baicalein & $\downarrow \mathrm{MCP}-1$ and TNF- $\alpha$ levels & [45] \\
\hline Mouse model (HFD) & RES & $\downarrow$ macrophage infiltration & [46] \\
\hline Mouse model (MCD) & Curcumin & $\begin{array}{l}\downarrow \text { ICAM-1, COX-2 and MCP-1 expressions, } \\
\text { NF- } \mathrm{KB} \text { signalling }\end{array}$ & [47] \\
\hline Mouse model (MCD) & Curcumin & $\downarrow$ ROS production & [48] \\
\hline Mouse model (MCD) & Silibinin & $\begin{array}{c}\downarrow \text { ROS production, iNOS expression, } \\
\text { NF- } \kappa \text { B activation }\end{array}$ & [49] \\
\hline Mouse model (MCD) & Silibinin & $\downarrow$ Il- 6 and TNF- $\alpha$ expressions; $\uparrow$ GSH level & {$[50]$} \\
\hline Rat model (HFD) & Quercetin & $\begin{array}{c}\downarrow \text { NF- } \kappa \text { B expression; } \\
\uparrow \text { Nrf2 and HO-1 expressions }\end{array}$ & [51] \\
\hline Rat model (HFD) & Rutin & $\downarrow$ plasma MDA; $\uparrow$ GPx expression & [52] \\
\hline Rat model (HFD) & EGCG & $\downarrow$ plasma and liver MDA; $\uparrow$ GSH level & [53] \\
\hline Rat model (HFD) & EGCG & $\begin{array}{c}\downarrow \text { iNOS, COX- } 2 \text { and TNF- } \alpha \text { expressions; } \\
\uparrow \text { GPx and CAT activity }\end{array}$ & [54] \\
\hline Rat model (HFD) & Genistein & $\downarrow$ TNF- $\alpha$ and plasma and liver MDA levels & [55] \\
\hline Rat model (HCD) & Naringenin & $\begin{array}{l}\downarrow \text { ROS production, TNF- } \alpha, \text { IL-6, IL-1 } \beta \text { and } \\
\text { iNOS expressions }\end{array}$ & [56] \\
\hline Rat model (HFD) & Coffee polyphenols & $\begin{array}{c}\downarrow \text { TNF- } \alpha, \text { IFN- } \gamma, \text { IL-4 and IL-10 expressions; } \\
\uparrow \text { GSH/GSSG ratio, }\end{array}$ & [57] \\
\hline Rat model (HFD) & Coffee polyphenols & $\uparrow$ GST expression & [58] \\
\hline Rat model (fructose-fed) & RES & $\begin{array}{c}\downarrow \text { TBARS level; } \uparrow \text { SOD activity, Nrf2 and } \\
\text { GSH levels }\end{array}$ & [59] \\
\hline
\end{tabular}


Table 2. Cont.

\begin{tabular}{|c|c|c|c|}
\hline Model of Study & Agent & Effects & Reference \\
\hline \multicolumn{4}{|l|}{ Human } \\
\hline Subjects with NAFLD & Catechins & $\begin{array}{c}\downarrow \text { urinary } F_{2 t} \text {-isoprostane excretion } \\
\text { (high dose) }\end{array}$ & {$[60]$} \\
\hline Subjects with NAFLD & RES & $\begin{array}{l}\downarrow \text { inflammatory markers } \\
\text { (TNF- } \alpha, \text { CK-18, FGF-21) }\end{array}$ & {$[61]$} \\
\hline Subjects with NAFLD & RES & $\begin{array}{l}\downarrow \text { inflammatory markers } \\
(\text { IL-6, hs-CRP, NF-kB) }\end{array}$ & [62] \\
\hline Subjects with NAFLD & Silymarin & $\downarrow$ NASH score and serum oxidative stress & [63] \\
\hline Subjects with NAFLD & RES & $\uparrow$ ALT and AST levels (high dose) & {$[64]$} \\
\hline \multicolumn{4}{|c|}{$\begin{array}{l}\uparrow: \text { increase; } \downarrow \text { : decrease; ALT: alanine aminotransferase; AST: aspartate transaminase; C3G: cyanidin-3-glucoside; } \\
\text { CAT; catalase; CK: cytokeratin; COX: cyclooxygenase; EGCG: epigallocatechin gallate; FGF: fibroblast growth factor; } \\
\text { GCL: glutamate-cysteine ligase; GPx: glutathione peroxidase; GSH: reduced glutathione; GSSG: oxidized glutathione; } \\
\text { GST: glutathione s-transferase; HFD: high fat diet; HO: heme oxygenase; hs-CRP: high sensitivity C-reactive } \\
\text { protein; ICAM: intercellular adhesion molecule; IFN- } \gamma \text { : interferon gamma; IL: interleukin; iNOS: inducible nitric } \\
\text { oxide synthase; MCD: methionine-choline deficient; MCDHFD: methionine-choline deficient high fat diet; } \\
\text { MCP: monocyte chemoattractant protein; MDA: malondialdehyde; NAFLD: non-alcoholic fatty liver disease; } \\
\text { NASH: non-alcoholic steatohepatitis; NF-kB: nuclear factor kappa B; Nrf: nuclear factor erythroid 2-related factor; } \\
\text { RES: resveratrol; ROS: reactive oxygen species; SOD: superoxide dismutase; TBARS: thiobarbituric acid reactive } \\
\text { substances; TG: triglyceride; TLR: toll-like receptor; TNF- } \alpha \text { : tumour necrosis factor alpha. }\end{array}$} \\
\hline
\end{tabular}

\subsection{In Vitro Models of Polyphenol Treatment in Liver Inflammation}

A few in vitro studies have illustrated the beneficial outcomes of polyphenols on oxidative stress and inflammation. Mouse macrophages pre-treated with rutin attenuated oxidative stress and MCP-1, TNF- $\alpha, I L-6, I F N-\gamma, I L-1 \beta$ genes expressions [40]. In a study on human hepatocyte HepG2 cells, the glutamate cysteine ligase (GCL) activity and GSH level were improved with cyanidin-3-O- $\beta$-glucoside (C3G) treatment [39]. Moreover, theaflavins could reduce ROS generation in the same type of cell line [38]. Curcumin treatment also increased GCL activity and GSH level, and attenuated ROS production in glucose-induced hepatic stellate cells [37].

\subsection{In Vivo Models of Polyphenol Treatment in Liver Inflammation}

Much like the in vitro studies, several animal in vivo studies have demonstrated encouraging effects of polyphenol interventions. Quercetin has shown to improve thiobarbituric acid reactive substances (TBARS), GPx and CAT levels, and down-regulate TNF- $\alpha$, IL-6 and COX-2 mRNA expressions in two mouse models [41,42]. Moreover, it was reported that the TLR4 protein concentration also decreased [42].

In mice fed with HFD, the expressions of TNF- $\alpha$ and MCP-1 genes were attenuated by rutin [40]. In another study, troxerutin increased GPx, SOD and GSH levels, which subsequently reduced ROS production [43]. Theaflavins supplementation lowered TBARS, ROS and TNF- $\alpha$ production in mice fed with a methionine and choline deficient high fat diet (HFD) [44]. Furthermore, the levels of MCP-1 and TNF- $\alpha$ were decreased with baicalein supplementation in HFD mice [45]. Oxidative stress could be reduced through the inhibition of macrophage infiltration when HFD mice are treated with RES [46]. In a few studies in which mice were given a methionine and choline-deficient diet, oxidative stress and inflammation were reduced with curcumin $[47,48]$. One of the studies reported the attenuation of ICAM-1, COX-2 and MCP-1 expressions and NF- $\mathrm{kB}$ signaling [47]. Another phenolic compound, silibinin, was shown to reduce iNOS expression, ROS production and NF- $\mathrm{KB}$ activation in mice fed with methionine and choline-deficient diet [49]. In addition, a similar model reported that silibinin supplementation improved GSH levels, and down-regulated IL-6 and TNF- $\alpha$ expressions [50].

Besides mouse models, polyphenol intervention has been studied in rat models. In rats fed with HFD, quercetin supplementation upregulated the expressions of $\mathrm{Nrf} 2$ and heme oxygenase 1 
(HO-1), and down-regulated the expression of NF-kB [51]. In a similar model, mice supplemented with rutin had higher GPx expression and lower plasma MDA levels [52]. One study showed that, with EGCG supplementation, the GSH level was improved, whereas the plasma and liver MDA levels were reduced in rats fed with HFD [53]. Furthermore, EGCG could increase GPx and CAT activity, and attenuate iNOS, COX-2 and TNF- $\alpha$ expressions [54]. Similarly, genistein treatment decreased TNF- $\alpha$, and plasma and liver MDA levels in HFD-fed rats [55]. In rats fed with a high cholesterol diet and naringenin, the attenuation of the production of pro-inflammatory cytokines, namely TNF- $\alpha$, IL-6 and IL-1 $\beta$, through the inhibition of the NF- $\mathrm{KB}$ pathway was also reported [56]. In fructose fed rats, RES increased SOD activity and Nrf2 and GSH levels [59]. Furthermore, RES reduced lipid peroxidation in the same model. The effects of coffee polyphenols have also been studied in a few rat models. The supplementation of coffee polyphenols ameliorated GSH/glutathione disulphide (GSSG) ratio, and attenuated TNF- $\alpha$ and IFN- $\gamma$ expressions [57]. Besides, coffee polyphenols could reduce hepatic oxidative stress and steatosis in rats fed with HFD [58]. It was also reported that coffee polyphenols suppressed not only the expressions of pro-inflammatory cytokines, but also suppressed the expressions of anti-inflammatory cytokines, such as IL-4 and IL-10 [57].

A few of the polyphenols have also been subject to clinical testing, with the target group being the patients with NAFLD. For instance, supplementation of catechins decreased urinary $\mathrm{F}_{2 \mathrm{t}}$-isoprostane excretion in the treatment group that was given a higher dose [60]. Moreover, silymarin supplementation ameliorated the NASH score and serum oxidative stress [63]. A few studies have tested the effects of RES in NAFLD patients and have produced mixed results. Several studies observed an improvement in the inflammatory markers, such as TNF- $\alpha$, cytokeratin 18 (CK-18), IL-6 and NF-kB [61,62]. On the other hand, one study reported the harmful effects of a high concentration of RES, in which the levels of enzymes, like alanine aminotransferase (ALT) and aspartate transaminase (AST) increased [64]. These findings suggest that polyphenols could prevent the progression of NAFLD to NASH. However, supplementation of a high dose could have adverse effects on liver health.

\section{Polyphenol Intervention in Gut Inflammation}

Compared to the other organs that have been discussed in this review, polyphenol intervention in gut inflammation had not been a subject of profound research until recently. Most of the research has been on berry polyphenols and RES $[65,66]$. The interventions have targeted the models of inflammatory bowel disease, which is a term used to describe inflammatory disorders in the gut [66]. Some common examples of inflammatory bowel disease include Crohn's disease and ulcerative colitis (UC) [66]. The findings of polyphenol interventions in vitro and in vivo studies in the last 15 years (2004-2019) are summarized in Table 3. 
Table 3. Summary of the effects of polyphenols on gut inflammation in the last 15 years (2004-2019).

\begin{tabular}{|c|c|c|c|}
\hline Model of Study & Agent & Effects & Reference \\
\hline \multicolumn{4}{|l|}{ In vitro } \\
\hline Human colon epithelial cells (cytokine-treated) & Anthocyanins & $\downarrow$ IP-10 and TNF- $\alpha$ expression & [67] \\
\hline Human monocytic THP- 1 cells (IFN- $\gamma$-treated) & Anthocyanins & $\downarrow$ IFN- $\gamma$ receptor 2 expression & {$[68]$} \\
\hline Human intestinal Caco-2 cells (LPS-treated) & RES & $\downarrow$ COX-2 expression, PGE2 release, NF- $\kappa$ B activation & [69] \\
\hline Human intestinal Caco-2 cells (LPS-treated) & RES & $\begin{array}{c}\downarrow \text { iNOS and TLR4 expression, NF-kB activation, } \\
\text { NO release (high dose) }\end{array}$ & [70] \\
\hline Human intestinal Caco- 2 cells (IL- $1 \beta$-treated) & RES & $\uparrow \mathrm{NF}-\kappa \mathrm{B}$ activation, $\mathrm{p}-\mathrm{I} \kappa \mathrm{B} / \mathrm{I} \kappa \mathrm{B}$ ratio, IL-8 production & [71] \\
\hline Human intestinal Caco- 2 cells (TNF- $\alpha$-treated) & RES & $\uparrow N F-\kappa B$ activation & [71] \\
\hline Human colon epithelial HT-29 cells (cytokine-treated) & RES & $\begin{array}{l}\downarrow \text { ROS production, iNOS and COX-2 expression, } \\
\text { NO and PGE2 release; } \leftrightarrow \text { NF- } \kappa \text { B activation }\end{array}$ & [72] \\
\hline Human colon epithelial HT-29 cells (cytokine-treated) & RES & $\begin{array}{c}\uparrow \text { HO-1 and GCL expression, Nrf2 activation, } \\
\text { GSH:GSSG ratio }\end{array}$ & [73] \\
\hline Human colon SW480 cells (LPS-treated) & RES & $\begin{array}{c}\downarrow \text { iNOS and TLR4 expression, NF-kB activation, } \\
\text { and NO release (high dose) }\end{array}$ & {$[70]$} \\
\hline \multicolumn{4}{|l|}{ Animal } \\
\hline Mouse model (TNBS-induced colitis) & Anthocyanins & $\begin{array}{l}\downarrow \text { MPO activity, IL-12, TNF- } \alpha \text { and IFN- } \gamma \text { increase, } \\
\text { NO production; } \uparrow \text { IL-10 expression }\end{array}$ & [74] \\
\hline Mouse model (DSS-induced colitis) & Blueberry extract & $\begin{array}{c}\downarrow \text { COX-2, iNOS, IFN- } \gamma \text { and IL-1 } \beta \text { expression, } \\
\text { NF- } \kappa \text { B activation, neutrophil infiltration, } \\
\text { MDA and serum PGE2 levels; } \uparrow \text { CAT and SOD activity }\end{array}$ & [75] \\
\hline Mouse model (DSS-induced colitis) & Black raspberry powder & $\begin{array}{c}\downarrow \text { TNF- } \alpha \text { and IL-1 } \beta \text { expression, NF- }-\mathrm{B} \text { and COX-2 activity; } \\
\leftrightarrow \text { RNS and MDA levels, inflammatory cells infiltration }\end{array}$ & [76] \\
\hline Mouse model (DSS-induced colitis) & Anthocyanins & $\downarrow$ TNF- $\alpha$ and IFN- $\gamma$ secretion & [77] \\
\hline Mouse model (DSS-induced colitis) & Black raspberry powder & $\begin{array}{l}\downarrow \text { macrophages and neutrophils infiltration, } \\
\text { NF- } \mathrm{KB} \text { translocation }\end{array}$ & [78] \\
\hline Mouse model (DSS-induced colitis) & $\begin{array}{l}\text { Cranberry extract or dried } \\
\text { cranberries }\end{array}$ & $\downarrow$ MPO activity, TNF- $\alpha$ and IL-1 $\beta$ expression & [79] \\
\hline
\end{tabular}


Table 3. Cont

\begin{tabular}{|c|c|c|c|}
\hline Model of Study & Agent & Effects & Reference \\
\hline Mouse model (high fat diet) & Cranberry extract & $\begin{array}{l}\downarrow \text { COX-2 and TNF- } \alpha \text { expression, LPS level; } \\
\qquad \text { MDA and SOD levels }\end{array}$ & {$[80]$} \\
\hline Mouse model (DSS-induced colitis) & RES & $\downarrow$ iNOS, COX-2 and TNF- $\alpha$ levels & {$[81]$} \\
\hline Mouse model (DSS-induced colitis) & RES & $\begin{array}{c}\downarrow \text { iNOS and COX-2 expression, TNF- } \alpha \text { and IL- } 1 \beta \text { levels; } \\
\uparrow \text { IL-10 level }\end{array}$ & [82] \\
\hline Mouse model (DSS-induced colitis) & RES & $\begin{array}{l}\downarrow \text { IL- } 6, \text { TNF- } \alpha, \text { IFN- } \gamma \text { and IL- } 1 \beta \text { levels, } \\
\text { COX- } 1 \text { and COX- } 2 \text { expression }\end{array}$ & [83] \\
\hline Mouse model (DSS-induced colitis) & RES & $\leftrightarrow$ MPO activity and TNF- $\alpha$ level & [84] \\
\hline Mouse model (DSS-induced colitis) & RES & $\begin{array}{l}\downarrow \mathrm{MPO}, \text { SOD and GPx activity, MDA level, TNF- } \alpha, \\
\text { IFN- } \gamma \text { and IL- } 8 \text { expression }\end{array}$ & [85] \\
\hline Mouse model (DSS-induced colitis) & RES & $\leftrightarrow$ MPO activity, PGE2, IL-6 and IL-10 levels & [86] \\
\hline Mouse model (DSS-induced colitis) & RES & $\downarrow$ iNOS level, NF- $\kappa B$ and IкB activation & [87] \\
\hline Mouse model (DSS-induced colitis) & RES & $\downarrow$ TNF- $\alpha$ level, COX-2 and IL-6 expression & [88] \\
\hline Mouse model (Spontaneous chronic colitis) & RES & $\downarrow$ IL-6, IL-12, TNF- $\alpha$, IFN- $\gamma$ and IL- $1 \beta$ levels & [89] \\
\hline Rat model (DSS-induced colitis) & Blueberry powder & $\begin{array}{l}\downarrow \mathrm{MPO} \text { activity, MDA concentration; } \\
\leftrightarrow \mathrm{MCP}-1 \text { and GRO/CINC- } 1 \text { levels }\end{array}$ & {$[90]$} \\
\hline Rat model (TNBS-induced colitis) & RES & $\begin{array}{c}\downarrow \mathrm{MPO} \text { activity, VCAM-1, ICAM-1, MDA, } \\
\text { NO and GSH levels }\end{array}$ & [91] \\
\hline Rat model (TNBS-induced colitis) & RES & $\begin{array}{c}\downarrow \text { MPO activity, GSH level, ICAM-1, MCP-1, CINC-1, } \\
\text { TNF- } \alpha, \text { IL-1 } \beta, \text { IL-6 and IL-12 expression }\end{array}$ & [92] \\
\hline Rat model (TNBS-induced colitis) & RES & $\downarrow$ MPO activity, IL-1 $\beta$, PGE2 and PGD2 levels & [93] \\
\hline Rat model (TNBS-induced colitis) & RES & $\begin{array}{c}\downarrow \text { MPO activity, TNF- } \alpha \text { level, COX-1, COX-2 and NF-kB p65 } \\
\text { expression; } \uparrow \text { PGE2 level; } \leftrightarrow \text { PGD2 level }\end{array}$ & [94] \\
\hline Rat model (TNBS-induced colitis) & RES & $\downarrow$ MDA level; $\uparrow$ GPx activity; $\leftrightarrow$ MPO, SOD, CAT activities & [95] \\
\hline Rat model (Methotrexate-induced colitis) & RES & $\downarrow$ MDA and GSH levels, MPO expression & [96] \\
\hline Rat model (Oxazolone-induced colitis) & RES & $\downarrow$ MPO activity & [97] \\
\hline
\end{tabular}


Table 3. Cont.

\begin{tabular}{|c|c|c|c|}
\hline Model of Study & Agent & Effects & Reference \\
\hline Rat model (DSS-induced colitis) & RES & $\downarrow$ COX-2, PGE2 and NO levels; $\leftrightarrow$ TBARS level & [98] \\
\hline Rat model (PG-PS-induced colitis) & RES & $\downarrow$ IL-6, TNF- $\alpha$ and IL-1 $\beta$ expression & [99] \\
\hline \multicolumn{4}{|l|}{ Human } \\
\hline Subjects with UC & Anthocyanins & $\begin{array}{c}\downarrow \mathrm{TNF}-\alpha, \text { IFN- } \gamma \text { and MCP-1 levels, NF- } \mathrm{kB} \text { activation; } \\
\uparrow \text { IL-22, IL-10 and IL-17A levels }\end{array}$ & {$[68]$} \\
\hline Subjects with mild to moderate UC & Anthocyanins & $\downarrow$ faecal calprotectin level and Riley Index & [100] \\
\hline Subjects with UC & RES & $\begin{array}{c}\downarrow \text { hs-CRP, TNF- } \alpha \text { levels, PBMC NF- } \kappa \text { B activation; } \\
\uparrow \text { IBDQ-9 score; } \leftrightarrow \text { SCCAI score }\end{array}$ & [101] \\
\hline Subjects with mild to moderate UC & RES & $\downarrow$ MDA level; $\uparrow$ SOD activity, IBDQ-9 score; $\leftrightarrow$ SCCAI score & [102] \\
\hline
\end{tabular}

$\uparrow$ : increase; $\downarrow$ : decrease; $\leftrightarrow$ : insignificant change; CAT; catalase; CINC: cytokine-induced neutrophil chemoattractant; COX: cyclooxygenase; DSS: dextran sodium sulphate; GCL: glutamate-cysteine ligase; GPx: glutathione peroxidase; GSH: reduced glutathione; GSSG: oxidized glutathione; HO: heme oxygenase; hs-CRP: high sensitivity C-reactive protein; ICAM: intercellular adhesion molecule; IFN- $\gamma$ : interferon gamma; IL: interleukin; IP: IFN- $\gamma$-induced protein; iNOS: inducible nitric oxide synthase; LPS: lipopolysaccharide; MCP: monocyte chemoattractant protein; MDA: malondialdehyde; MPO: myeloperoxidase; NF-kB: nuclear factor kappa B; NO: nitric oxide; Nrf: nuclear factor erythroid 2-related MCP: monocyte chemoattractant protein; MDA: malondialdehyde; MPO: myeloperoxidase; NF-kB: nuclear factor kappa B; NO: nitric oxide; Nrf: nuclear factor erythroid 2-related species; ROS: reactive oxygen species; SOD: superoxide dismutase; TBARS: thiobarbituric acid reactive substances; TLR: toll-like receptor; TNBS: 2, 4, 6-Trinitrobenzenesulfonic acid; TNF- $\alpha$ : tumour necrosis factor alpha; UC: ulcerative colitis; VCAM: vascular cell adhesion molecule. 


\subsection{In Vitro Models of Polyphenol Treatment in Gut Inflammation}

Much like the brain and liver, quite a few studies have been conducted to evaluate the effects of polyphenols on gut health. The amelioration of oxidative stress and inflammatory markers has been observed in several in vitro studies on human intestinal cell lines. For example, the expressions of TNF- $\alpha$, IFN- $\gamma$-induced protein 10 (IP-10) and IFN- $\gamma$ receptor 2 were inhibited by anthocyanins $[67,68]$. One study demonstrated the beneficial effects of RES in human intestinal Caco-2 cells treated with LPS. It was reported that RES pre-treatment suppressed COX-2 expression, prostaglandin E2 (PGE2) release and NF- $\mathrm{B}$ activation [69]. In a similar study, iNOS and TLR4 expression, NF- $\mathrm{kB}$ activation and NO release were reduced but only in high RES concentration treatment groups [70]. The same results were obtained from RES treatment in human colon SW480 cells [70]. Moreover, RES upregulated HO-1 and GCL expression through the activation of the Nrf2 pathway and improved the GSH/GSSG ratio in human colon epithelial HT-29 cells [73]. Besides, ROS production, iNOS and COX-2 expression, and NO and PGE2 release could be attenuated with RES. However, it had no significant effect on the activation of NF- $\kappa$ B [72]. In Caco- 2 cells stimulated by IL-1 $\beta$ or TNF- $\alpha$, the phosphorylation of I $\kappa B$ could not be inhibited by RES, which allowed the activation of NF- $\mathrm{KB}$ [71]. This shows that stimulation by pro-inflammatory cytokines could trigger the inflammatory cascade even in the presence of an anti-inflammatory agent like RES.

\subsection{In Vivo Models of Polyphenol Treatment in Gut Inflammation}

In vivo animal models have also been used to better understand the impact of polyphenols. In a rat model of colitis induced by dextran sodium sulphate (DSS), blueberry powder reduced myeloperoxidase (MPO) activity and MDA concentration, but had an insignificant effect on MCP-1 level [90]. MPO activity is used to determine neutrophil infiltration, where a high activity would represent higher oxidative stress [65]. In another rat model of DSS-induced colitis, RES treatment decreased COX-2, PGE2 and NO levels. However, no significant change occurred in the TBARS level [98]. Another substance used to induce colitis in animal models is 2, 4, 6-trinitrobenzenesulfonic acid (TNBS). One study observed the attenuation of MPO activity, and VCAM-1, ICAM-1, MDA, $\mathrm{NO}$ and GSH levels with RES administration [91]. In addition to these effects, RES administration suppressed the expressions of MCP-1, cytokine-induced neutrophil chemoattractant 1 (CINC-1), TNF- $\alpha$, IL-1 $\beta$, IL-6 and IL-12 in rats with TNBS-induced colitis [92]. Pre-treatment of rats with RES lowered MPO activity, and IL-1 $\beta$, PGE2 and prostaglandin D2 (PGD2) levels from TNBS-induced colitis [93]. In one study, even though the expression of certain inflammatory mediators was downregulated with RES treatment, the level PGE2 was increased [94]. Moreover, RES reduced colon MDA level and promoted GPx activity. Despite that, the MPO, SOD and CAT activities were unaffected [95]. In rats with methotrexate-induced or oxazolone-induced colitis, MPO activity was suppressed by RES administration [96,97]. Furthermore, the expression of pro-inflammatory cytokines, like IL-6, TNF- $\alpha$ and IL-1 $\beta$, was decreased in a peptidoglycan-polysaccharide-induced colitis rat model [99].

Similar effects were demonstrated in mice models. Anthocyanins inhibited MPO activity, and the increase of pro-inflammatory cytokines in mice with TNBS-induced colitis. At the same time, the expression of the anti-inflammatory cytokine, IL-10, was upregulated [74]. Same effects were observed in both acute and chronic inflammatory conditions in a different study [77]. One study reported the suppression of inflammatory mediators and neutrophil infiltration, and the increase of CAT and SOD activity with blueberry extract. However, these effects were more prominent in the pre-treated group than the post-treated group [75]. Likewise, black raspberry extract attenuated TNF- $\alpha$ and IL-1 $\beta$ expressions, and NF- $\kappa$ B and COX-2 activity in mice with DSS-induced colitis. Yet, it had no significant effect on MDA and inflammatory cells infiltration [76]. Another study showed the inhibition of macrophages and neutrophils infiltration, and NF-kB nuclear translocation [78]. In a study on cranberry extract and dried cranberries treatment, dried cranberries attenuated MPO activity and pro-inflammatory cytokines production [79]. In mice that were given an HFD, cranberry extract downregulated the expression of inflammatory mediators but had an insignificant effect on MDA and 
SOD levels [80]. RES intervention has also been studied in various DSS-induced colitis mouse models. One study recorded a decrease in protein levels of iNOS, COX-2 and TNF- $\alpha$ [81]. Similar effects were observed in another study alongside an increase in IL-10 level [82]. In addition, a few studies showed an attenuation in the levels of pro-inflammatory cytokines and inflammatory enzymes with RES administration [83,88]. Moreover, RES supplementation reduced iNOS protein levels and NF- $\kappa B$ activation in colons of mice with DSS-induced colitis [87]. In mice with spontaneous chronic colitis, RES administration for 28 weeks decreased the levels of pro-inflammatory cytokines in the colon and serum [89]. On the other hand, RES had no significant impact on MPO activity and levels of TNF- $\alpha$, PGE2, IL-6 and IL-10 in mouse models of DSS-induced colitis [84,86]. Although the MPO activity and the expressions of pro-inflammatory cytokines were downregulated, Yao et al. found the SOD and GPx activities to be suppressed as well [85].

Several studies have been conducted on polyphenol intervention in patients with UC. For instance, anthocyanins were reported to reduce TNF- $\alpha$, IFN- $\gamma$ and MCP-1 levels and NF- $\mathrm{BB}$ activation. In the same study, the levels of IL-22, IL-10 and IL-17A were elevated [68]. One study on subjects with mild to moderate UC showed a reduction in fecal calprotectin level with anthocyanins treatment, which suggests that neutrophil migration was lowered. However, an increase in disease activity was observed after the termination of the treatment [100]. Besides anthocyanins, RES has also been tested in subjects with UC. One study reported a decrease in high-sensitivity CRP and TNF- $\alpha$ levels, and the suppression of NF- $\kappa$ B activation [101]. Additionally, RES administration in patients with mild to moderate UC ameliorated plasma SOD activity and lessened plasma MDA level [102]. Even though there have been encouraging results from some clinical interventions, more clinical trials are required to consider polyphenols as potential therapeutics for gut inflammatory diseases.

\section{Research Gap}

Although polyphenols have demonstrated anti-inflammatory properties in vitro and in vivo animal studies, there is inconclusive evidence of their effects in humans. Currently, there is insufficient evidence to support the use of polyphenols as therapeutics in subjects with inflammatory diseases. There is a need for more human trials on polyphenol intervention to gain more conclusive evidence. Moreover, it is worth noting that the available human studies have only demonstrated symptom amelioration in subjects with inflammatory diseases. For instance, RES administration reduced inflammation in Alzheimer's disease patients [34]. Other studies also reported the amelioration of symptoms with polyphenol supplementation in subjects with liver inflammatory diseases [60-63]. Furthermore, remission was observed from clinical interventions related to polyphenol administration in gut inflammatory disease patients [68,100-102]. Albeit these trials demonstrated beneficial effects, they could not demonstrate complete resolution of inflammation. As a result, it is rather premature to use polyphenols to treat inflammatory diseases.

In addition, a few studies have shown that there could be harmful effects associated with polyphenol treatment. For example, studies have reported an increase in pro-inflammatory cytokine secretion and NF- $\mathrm{BB}$ activation $[16,71,94]$. A study also reported the downregulation of antioxidant enzymes [85]. In another report, it showed RES supplementation resulted in the deterioration of liver health in patients with NAFLD [64]. Most of these adverse effects have been related to the administered dose of polyphenols. Therefore, further research on the appropriate dosage of polyphenols to produce beneficial effects and prevent adverse effects is required to reach a consensus.

\section{Conclusions}

Several in vitro and in vivo animal studies have demonstrated the antioxidant and anti-inflammatory effects of polyphenols in the brain-liver-gut axis. Polyphenols have been shown to target different stages of the inflammatory cascade to reduce the severity of inflammation. In general, the natural antioxidants seem to be more useful in the prevention of inflammation rather than in resolution. Although some antioxidants have had promising effects in vitro and animal studies, 
those results could not be extrapolated to human studies. As a result, further research is needed on polyphenol intervention in human trials, and on ways to improve the bioavailability and efficacy of polyphenols in subjects with inflammatory diseases.

Author Contributions: A.S. wrote the manuscript. Y.F.Y., K.S.L., H.E.-N. and J.C.-Y.L. conceptualized the manuscript. J.C.-Y.L. revised the manuscript. All authors have read and agreed to the published version of the manuscript.

Funding: This research received no external funding.

Conflicts of Interest: The authors declare no conflict of interest.

\section{References}

1. Lugrin, J.; Rosenblatt-Velin, N.; Parapanov, R.; Liaudet, L. The role of oxidative stress during inflammatory processes. Biol. Chem. 2014, 395, 203-230. [CrossRef] [PubMed]

2. Zhang, J.M.; An, J. Cytokines, inflammation and pain. Int. Anesthesiol. Clin. 2007, 45, 27-37. [CrossRef] [PubMed]

3. Song, D.H.; Lee, J.O. Sensing of microbial molecular patterns by Toll-like receptors. Immunol. Rev. 2012, 250, 216-229. [CrossRef] [PubMed]

4. Chatterjee, S. Oxidative stress, inflammation, and disease. In Oxidative Stress and Biomaterials; Dziubla, T., Butterfield, D.A., Eds.; Academic Press: Cambridge, MA, USA, 2016; pp. 35-58.

5. Powers, K.A.; Szászi, K.; Khadaroo, R.G.; Tawadros, P.S.; Marshall, J.C.; Kapus, A.; Rotstein, O.D. Oxidative stress generated by hemorrhagic shock recruits Toll-like receptor 4 to the plasma membrane in macrophages. J. Exp. Med. 2006, 203, 1951-1961. [CrossRef] [PubMed]

6. Nakahira, K.; Kim, H.P.; Geng, X.H.; Nakao, A.; Wang, X.; Murase, N.; Drain, P.F.; Wang, X.; Sasidhar, M.; Nabel, E.G.; et al. Carbon monoxide differentially inhibits TLR signaling pathways by regulating ROS-induced trafficking of TLRs to lipid rafts. J. Exp. Med. 2006, 203, 2377-2389. [CrossRef]

7. Lawrence, T. The nuclear factor NF-kB pathway in inflammation. Cold Spring Harb. Perspect. Biol. 2009, 1, a001651. [CrossRef]

8. Ramos-Tovar, E.; Muriel, P. Free radicals, antioxidants, nuclear factor-E2-related factor-2 and liver damage. J. Appl. Toxicol. 2020, 40, 151-168. [CrossRef]

9. Pham-Huy, L.A.; He, H.; Pham-Huy, C. Free radicals, antioxidants in disease and health. Int. J. Biomed. Sci. 2008, 4, 89-96.

10. Magrone, T.; Magrone, M.; Russo, M.A.; Jirillo, E. Recent Advances on the Anti-Inflammatory and Antioxidant Properties of Red Grape Polyphenols: In Vitro and In Vivo Studies. Antioxidants 2020, 9, 35. [CrossRef]

11. Winter, A.N.; Bickford, P.C. Anthocyanins and Their Metabolites as Therapeutic Agents for Neurodegenerative Disease. Antioxidants 2019, 8, 333. [CrossRef]

12. Silva, R.F.; Pogačnik, L. Polyphenols from Food and Natural Products: Neuroprotection and Safety. Antioxidants 2020, 9, 61. [CrossRef] [PubMed]

13. Devassy, J.G.; Leng, S.; Gabbs, M.; Monirujjaman, M.; Aukema, H.M. Omega-3 polyunsaturated fatty acids and oxylipins in neuroinflammation and management of Alzheimer disease. Adv. Nutr. 2016, 7, 905-916. [CrossRef] [PubMed]

14. Testa, G.; Gamba, P.; Badilli, U.; Gargiulo, S.; Maina, M.; Guina, T.; Calfapietra, S.; Biasi, F.; Cavalli, R.; Poli, G.; et al. Loading into nanoparticles improves quercetin's efficacy in preventing neuroinflammation induced by oxysterols. PLoS ONE 2014, 9, e96795. [CrossRef] [PubMed]

15. Bhaskar, S.; Shalini, V.; Helen, A. Quercetin regulates oxidized LDL induced inflammatory changes in human PBMCs by modulating the TLR-NF-kB signaling pathway. Immunobiology 2011, 216, 367-373. [CrossRef]

16. Casedas, G.; Bennett, A.C.; Gonzalez-Burgos, E.; Gomez-Serranillos, M.P.; Lopez, V.; Smith, C. Polyphenol-associated oxidative stress and inflammation in a model of LPS-induced inflammation in glial cells: Do we know enough for responsible compounding? Inflammopharmacology 2019, 27, 189-197. [CrossRef]

17. Carey, A.N.; Fisher, D.R.; Rimando, A.M.; Gomes, S.M.; Bielinski, D.F.; Shukitt-Hale, B. Stilbenes and anthocyanins reduce stress signaling in BV-2 mouse microglia. J. Agric. Food Chem. 2013, 61, 5979-5986. [CrossRef] 
18. Lau, F.C.; Bielinski, D.F.; Joseph, J.A. Inhibitory effects of blueberry extract on the production of inflammatory mediators in lipopolysaccharide-activated BV2 microglia. J. Neurosci. Res. 2007, 85, 1010-1017. [CrossRef]

19. Lau, F.C.; Joseph, J.A.; McDonald, J.E.; Kalt, W. Attenuation of iNOS and COX2 by blueberry polyphenols is mediated through the suppression of NF-kB activation. J. Funct. Foods 2009, 1, 274-283. [CrossRef]

20. Poulose, S.M.; Fisher, D.R.; Larson, J.; Bielinski, D.F.; Rimando, A.M.; Carey, A.N.; Schauss, A.G.; Shukitt-Hale, B. Anthocyanin-rich acai (Euterpe oleracea Mart.) fruit pulp fractions attenuate inflammatory stress signaling in mouse brain BV-2 microglial cells. J. Agric. Food Chem. 2012, 60, 1084-1093. [CrossRef]

21. Jeong, J.W.; Lee, W.S.; Shin, S.C.; Kim, G.Y.; Choi, B.T.; Choi, Y.H. Anthocyanins downregulate lipopolysaccharide-induced inflammatory responses in BV2 microglial cells by suppressing the NF-kappaB and Akt/MAPKs signaling pathways. Int. J. Mol. Sci. 2013, 14, 1502-1515. [CrossRef]

22. Zhao, L.; Chen, S.; Liu, T.; Wang, X.; Huang, H.; Liu, W. Callistephin enhances the protective effects of isoflurane on microglial injury through downregulation of inflammation and apoptosis. Mol. Med. Rep. 2019, 20, 802-812. [CrossRef] [PubMed]

23. Shukitt-Hale, B.; Kelly, M.E.; Bielinski, D.F.; Fisher, D.R. Tart Cherry Extracts Reduce Inflammatory and Oxidative Stress Signaling in Microglial Cells. Antioxidants 2016, 5, 33. [CrossRef] [PubMed]

24. Pacheco, S.M.; Azambuja, J.H.; De Carvalho, T.R.; Soares, M.S.P.; Oliveira, P.S.; Da Silveira, E.F.; Stefanello, F.M.; Braganhol, E.; Gutierres, J.M.; Spanevello, R.M. Glioprotective Effects of Lingonberry Extract Against Altered Cellular Viability, Acetylcholinesterase Activity, and Oxidative Stress in Lipopolysaccharide-Treated Astrocytes. Cell. Mol. Neurobiol. 2018, 38, 1107-1121. [CrossRef] [PubMed]

25. Ben Youssef, S.; Brisson, G.; Doucet-Beaupré, H.; Castonguay, A.M.; Gora, C.; Amri, M.; Lévesque, M. Neuroprotective benefits of grape seed and skin extract in a mouse model of Parkinson's disease. Nutr. Neurosci. 2019, 25, 1-15. [CrossRef] [PubMed]

26. Capiralla, H.; Vingtdeux, V.; Zhao, H.; Sankowski, R.; Al-Abed, Y.; Davies, P.; Marambaud, P. Resveratrol mitigates lipopolysaccharide- and $\mathrm{A} \beta$-mediated microglial inflammation by inhibiting the TLR4/NF-kB/STAT signaling cascade. J. Neurochem. 2012, 120, 461-472. [CrossRef] [PubMed]

27. Seong, K.J.; Lee, H.G.; Kook, M.S.; Ko, H.M.; Jung, J.Y.; Kim, W.J. Epigallocatechin-3-gallate rescues LPS-impaired adult hippocampal neurogenesis through suppressing the TLR4-NF- $\kappa$ B signaling pathway in mice. Korean J. Physiol. Pharmacol. 2016, 20, 41-51. [CrossRef] [PubMed]

28. Khan, M.S.; Ali, T.; Kim, M.W.; Jo, M.H.; Chung, J.I.; Kim, M.O. Anthocyanins Improve Hippocampus-Dependent Memory Function and Prevent Neurodegeneration via JNK/Akt/GSK3beta Signaling in LPS-Treated Adult Mice. Mol. Neurobiol. 2019, 56, 671-687. [CrossRef]

29. Wang, Y.; Zheng, Y.; Lu, J.; Chen, G.; Wang, X.; Feng, J.; Ruan, J.; Sun, X.; Li, C.; Sun, Q. Purple sweet potato color suppresses lipopolysaccharide-induced acute inflammatory response in mouse brain. Neurochem. Int. 2010, 56, 424-430. [CrossRef]

30. Khan, M.S.; Ali, T.; Kim, M.W.; Jo, M.H.; Jo, M.G.; Badshah, H.; Kim, M.O. Anthocyanins protect against LPS-induced oxidative stress-mediated neuroinflammation and neurodegeneration in the adult mouse cortex. Neurochem. Int. 2016, 100, 1-10. [CrossRef]

31. Carvalho, F.B.; Gutierres, J.M.; Bueno, A.; Agostinho, P.; Zago, A.M.; Vieira, J.; Fruhauf, P.; Cechella, J.L.; Nogueira, C.W.; Oliveira, S.M.; et al. Anthocyanins control neuroinflammation and consequent memory dysfunction in mice exposed to lipopolysaccharide. Mol. Neurobiol. 2017, 54, 3350-3367. [CrossRef]

32. Li, J.; Shi, Z.; Mi, Y. Purple sweet potato color attenuates high fat-induced neuroinflammation in mouse brain by inhibiting MAPK and NF-kappaB activation. Mol. Med. Rep. 2018, 17, 4823-4831. [PubMed]

33. Pan, Z.; Cui, M.; Dai, G.; Yuan, T.; Li, Y.; Ji, T.; Pan, Y. Protective Effect of Anthocyanin on Neurovascular Unit in Cerebral Ischemia/Reperfusion Injury in Rats. Front. Neurosci. 2018, 12, 947. [CrossRef] [PubMed]

34. Moussa, C.; Hebron, M.; Huang, X.; Ahn, J.; Rissman, R.A.; Aisen, P.S.; Turner, R.S. Resveratrol regulates neuro-inflammation and induces adaptive immunity in Alzheimer's disease. J. Neuroinflamm. 2017, $14,1$. [CrossRef] [PubMed]

35. Elvira-Torales, L.I.; García-Alonso, J.; Periago-Castón, M.J. Nutritional importance of carotenoids and their effect on liver health: A review. Antioxidants 2019, 8, 229. [CrossRef]

36. Salomone, F.; Godos, J.; Zelber-Sagi, S. Natural antioxidants for non-alcoholic fatty liver disease: Molecular targets and clinical perspectives. Liver Int. 2016, 36, 5-20. [CrossRef] [PubMed] 
37. Lin, J.; Tang, Y.; Kang, Q.; Feng, Y.; Chen, A. Curcumin inhibits gene expression of receptor for advanced glycation end-products (RAGE) in hepatic stellate cells in vitro by elevating PPARgamma activity and attenuating oxidative stress. Br. J. Pharmacol. 2012, 166, 2212-2227. [CrossRef]

38. Lin, C.L.; Huang, H.C.; Lin, J.K. Theaflavins attenuate hepatic lipid accumulation through activating AMPK in human HepG2 cells. J. Lipid Res. 2007, 48, 2334-2343. [CrossRef]

39. Zhu, W.; Jia, Q.; Wang, Y.; Zhang, Y.; Xia, M. The anthocyanin cyanidin-3-O-beta-glucoside, a flavonoid, increases hepatic glutathione synthesis and protects hepatocytes against reactive oxygen species during hyperglycemia: Involvement of a cAMP-PKA-dependent signaling pathway. Free. Radic. Biol. Med. 2012, 52, 314-327. [CrossRef]

40. Gao, M.; Ma, Y.; Liu, D. Rutin suppresses palmitic acids- triggered inflammation in macrophages and blocks high fat diet-induced obesity and fatty liver in mice. Pharm. Res. 2013, 30, 2940-2950. [CrossRef]

41. Kobori, M.; Masumoto, S.; Akimoto, Y.; Oike, H. Chronic dietary intake of quercetin alleviates hepatic fat accumulation associated with consumption of a Western-style diet in C57/BL6J mice. Mol. Nutr. Food Res. 2011, 55, 530-540. [CrossRef]

42. Marcolin, E.; San-Miguel, B.; Vallejo, D.; Tieppo, J.; Marroni, N.; González-Gallego, J.; Tuñón, M.J. Quercetin treatment ameliorates inflammation and fibrosis in mice with nonalcoholic steatohepatitis. J. Nutr. 2012, 142, 1821-1828. [CrossRef] [PubMed]

43. Zhang, Z.-F.; Fan, S.-H.; Zheng, Y.-L.; Lu, J.; Wu, D.-M.; Shan, Q.; Hu, B. Troxerutin improves hepatic lipid homeostasis by restoring $\mathrm{NAD}(+)$-depletion-mediated dysfunction of lipin 1 signaling in high-fat diet-treated mice. Biochem. Pharmacol. 2014, 91, 74-86. [CrossRef] [PubMed]

44. Luo, X.Y.; Takahara, T.; Hou, J.; Kawai, K.; Sugiyama, T.; Tsukada, K.; Takemoto, M.; Takeuchi, M.; Zhong, L.; $\mathrm{Li}, \mathrm{X} . \mathrm{K}$. Theaflavin attenuates ischemia-reperfusion injury in a mouse fatty liver model. Biochem. Biophys. Res. Commun. 2012, 417, 287-293. [CrossRef] [PubMed]

45. Pu, P.; Wang, X.A.; Salim, M.; Zhu, L.-H.; Wang, L.; Chen, K.-J.; Xiao, J.-F.; Deng, W.; Shi, H.-W.; Jiang, H.; et al. Baicalein, a natural pro- duct, selectively activating AMPKalpha(2) and ameliorates metabolic disorder in diet-induced mice. Mol. Cell Endocrinol. 2012, 362, 128-138. [CrossRef]

46. Jeon, B.T.; Jeong, E.A.; Shin, H.J.; Lee, Y.; Lee, N.H.; Kim, H.J.; Kang, S.S.; Cho, G.J.; Choi, W.S.; Roh, G.S. Resveratrol attenuates obesity-associated peripheral and central inflammation and improves memory deficit in mice fed a high-fat diet. Diabetes 2012, 61, 1444-1454. [CrossRef]

47. Leclercq, I.A.; Farrell, G.C.; Sempoux, C.; Dela Pena, A.; Hors-mans, Y. Curcumin inhibits NF-kappaB activation and reduces the severity of experimental steatohepatitis in mice. J. Hepatol. 2004, 41, 926-934. [CrossRef]

48. Vizzutti, F.; Provenzano, A.; Galastri, S.; Milani, S.; Delogu, W.; Novo, E.; Caligiuri, A.; Zamara, E.; Arena, U.; Laffi, G.; et al. Curcumin limits the fibrogenic evolution of experimental steatohepatitis. Lab. Investig. 2010, 90, 104-115. [CrossRef]

49. Salamone, F.; Galvano, F.; Cappello, F.; Mangiameli, A.; Barbagallo, I.; Volti, G.L. Silibinin modulates lipid homeostasis and inhibits nuclear factor kappa B activation in experimental nonalcoholic steatohepatitis. Transl. Res. 2012, 159, 477-486. [CrossRef]

50. Salamone, F.; Galvano, F.; Marino Gammazza, A.; Paternostro, C.; Tibullo, D.; Bucchieri, F.; Mangiameli, A.; Parola, M.; Bugianesi, E.; Volti, G.L. Silibinin improves hepatic and myocardial injury in mice with nonalcoholic steatohepatitis. Dig. Liver Dis. 2012, 44, 334-342. [CrossRef]

51. Panchal, S.K.; Poudyal, H.; Brown, L. Quercetin ameliorates cardiovascular, hepatic, and metabolic changes in diet- induced metabolic syndrome in rats. J. Nutr. 2012, 142, 1026-1032. [CrossRef] [PubMed]

52. Panchal, S.K.; Poudyal, H.; Arumugam, T.V.; Brown, L. Rutin attenuates metabolic changes, nonalcoholic steatohepatitis, and cardiovascular remodeling in high-carbohydrate, high-fat diet-fed rats. J. Nutr. 2011, 141, 1062-1069. [CrossRef] [PubMed]

53. Kuzu, N.; Bahcecioglu, I.H.; Dagli, A.F.; Ozercan, I.H.; Ustundag, B.; Sahin, K. Epigallocatechin gallate attenuates experimental non-alcoholic steatohepatitis induced by high fat diet. J. Gastroenterol. Hepatol. 2008, 23, e465-e470. [CrossRef]

54. Xiao, J.; Ho, C.T.; Liong, E.C.; Nanji, A.A.; Leung, T.M.; Lau, T.Y.H.; Fung, M.L.; Tipoe, G.L. Epigallocatechin gallate attenuates fibrosis, oxidative stress, and inflammation in non-alcoholic fatty liver disease rat model through TGF/ SMAD, PI3 K/Akt/FoxO1, and NF-kappa B pathways. Eur. J. Nutr. 2014, 53, 187-199. [CrossRef] [PubMed] 
55. Yalniz, M.; Bahcecioglu, I.H.; Kuzu, N.; Poyrazoğlu, O.K.; Bulmus, Ö.; Celebi, S.; Ustundag, B.; Ozercan, I.H.; Sahin, K. Preventive role of genistein in an experimental non-alcoholic steatohepatitis model. J. Gastroenterol. Hepatol. 2007, 22, 2009-2014. [CrossRef] [PubMed]

56. Chtourou, Y.; Fetoui, H.; Jemai, R.; Ben Slima, A.; Makni, M.; Gdoura, R. Naringenin reduces cholesterol-induced hepatic inflammation in rats by modulating matrix metalloproteinases-2, 9 via inhibition of nuclear factor kappaB pathway. Eur. J. Pharmacol. 2015, 746, 96-105. [CrossRef]

57. Vitaglione, P.; Morisco, F.; Mazzone, G.; Amoruso, D.C.; Ribecco, M.T.S.; Romano, A.; Fogliano, V.; Caporaso, N.; D'Argenio, G. Coffee reduces liver damage in a rat model of steatohepatitis: The underlying mechanisms and the role of polyphenols and melanoidins. Hepatology 2010, 52, 1652-1661. [CrossRef] [PubMed]

58. Salomone, F.; Volti, G.L.; Vitaglione, P.; Morisco, F.; Fogliano, V.; Zappalà, A.; Palmigiano, A.; Garozzo, D.; Caporaso, N.; D'Argenio, G.; et al. Coffee enhances the expression of chaperones and antioxidant proteins in rats with nonalcoholic fatty liver disease. Transl. Res. 2014, 163, 593-602. [CrossRef] [PubMed]

59. Bagul, P.K.; Middela, H.; Matapally, S.; Padiya, R.; Bastia, T.; Madhusudana, K.; Reddy, B.R.; Chakravarty, S.; Banerjee, S.K. Attenuation of insulin resistance, metabolic syndrome and hepatic oxidative stress by resveratrol in fructose-fed rats. Pharmacol. Res. 2012, 66, 260-268. [CrossRef]

60. Sakata, R.; Nakamura, T.; Torimura, T.; Ueno, T.; Sata, M. Green tea with high-density catechins improves liver function and fat infiltration in non-alcoholic fatty liver disease (NAFLD) patients: A double-blind placebo-controlled study. Int. J. Mol. Med. 2013, 32, 989-994. [CrossRef]

61. Chen, S.; Zhao, X.; Ran, L.; Wan, J.; Wang, X.; Qin, Y.; Shu, F.; Gao, Y.; Yuan, L.; Zhang, Q.; et al. Resveratrol improves insulin resistance, glucose and lipid metabolism in patients with non-alcoholic fatty liver disease: A randomized controlled trial. Dig. Liver Dis. 2015, 47, 226-232. [CrossRef]

62. Faghihzadeh, F.; Adibi, P.; Rafiei, R.; Hekmatdoost, A. Resveratrol supplementation improves inflammatory biomarkers in patients with nonalcoholic fatty liver disease. Nutr. Res. 2014, 34, 837-843. [CrossRef]

63. Stiuso, P.; Scognamiglio, I.; Murolo, M.; Ferranti, P.; De Simone, C.; Rizzo, M.R.; Tuccillo, C.; Caraglia, M.; Loguercio, C.; Federico, A. Serum oxidative stress markers and lipidomic profile to detect NASH patients responsive to an antioxidant treatment: A pilot study. Oxid. Med. Cell Longev. 2014, 2014, 169216. [CrossRef] [PubMed]

64. Chachay, V.S.; Macdonald, G.A.; Martin, J.H.; Whitehead, J.; O’Moore-Sullivan, T.M.; Lee, P.; Franklin, M.; Klein, K.; Taylor, P.J.; Ferguson, M.; et al. Resveratrol does not benefit patients with nonalcoholic fatty liver disease. Clin. Gastroenterol. Hepatol. 2014, 12, 2092-2103. [CrossRef] [PubMed]

65. Lavefve, L.; Howard, L.R.; Carbonero, F. Berry polyphenols metabolism and impact on human gut microbiota and health. Food Funct. 2020, 11, 45-65. [CrossRef]

66. Nunes, S.; Danesi, F.; Del Rio, D.; Silva, P. Resveratrol and inflammatory bowel disease: The evidence so far. Nutr. Res. Rev. 2018, 31, 85-97. [CrossRef] [PubMed]

67. Triebel, S.; Trieu, H.L.; Richling, E. Modulation of inflammatory gene expression by a bilberry (Vaccinium myrtillus L.) extract and single anthocyanins considering their limited stability under cell culture conditions. J. Agric. Food Chem. 2012, 60, 8902-8910. [CrossRef]

68. Roth, S.; Spalinger, M.R.; Gottier, C.; Biedermann, L.; Zeitz, J.; Lang, S.; Weber, A.; Rogler, G.; Scharl, M. Bilberry-derived anthocyanins modulate cytokine expression in the intestine of patients with ulcerative colitis. PLoS ONE 2016, 11, e0154817. [CrossRef]

69. Cianciulli, A.; Calvello, R.; Cavallo, P.; Dragone, T.; Carofiglio, V.; Panaro, M.A. Modulation of NF-kB activation by resveratrol in LPS treated human intestinal cells results in downregulation of PGE2 production and COX-2 expression. Toxicol. In Vitro 2012, 26, 1122-1128. [CrossRef]

70. Panaro, M.A.; Carofiglio, V.; Acquafredda, A.; Cavallo, P.; Cianciulli, A. Anti- inflammatory effects of resveratrol occur via inhibition of lipopolysaccharide-induced NF-kB activation in Caco-2 and SW480 human colon cancer cells. Br. J. Nutr. 2012, 108, 1623-1632. [CrossRef]

71. Romier, B.; Van De Walle, J.; During, A.; Larondelle, Y.; Schneider, Y.-J. Modulation of signalling nuclear factor- $\mathrm{KB}$ activation pathway by polyphenols in human intestinal Caco-2 cells. Br. J. Nutr. 2008, 100, 542-551. [CrossRef]

72. Serra, D.; Rufino, A.T.; Mendes, A.F.; Almeida, L.M.; Dinis, T.C.P. Resveratrol modulates cytokine-induced Jak/STAT activation more efficiently than 5-aminosalicylic acid: An in vitro approach. PLoS ONE 2014, 9, e109048. [CrossRef] [PubMed] 
73. Serra, D.; Almeida, L.M.; Dinis, T.C. Anti-inflammatory protection afforded by cyanidin-3-glucoside and resveratrol in human intestinal cells via Nrf2 and PPAR- $\gamma$ : Comparison with 5-aminosalicylic acid. Chem. Biol. Interact. 2016, 260, 102-109. [CrossRef] [PubMed]

74. Wu, L.H.; Xu, Z.L.; Dong, D.; He, S.A.; Yu, H. Protective effect of anthocyanins extract from blueberry on TNBS-induced IBD model of mice. Evid. Based Complementary Altern. Med. 2011, 2011, 525462. [CrossRef] [PubMed]

75. Pervin, M.; Hasnat, M.A.; Lim, J.H.; Lee, Y.M.; Kim, E.O.; Um, B.H.; Lim, B.O. Preventive and therapeutic effects of blueberry (Vaccinium corymbosum) extract against DSS-induced ulcerative colitis by regulation of antioxidant and inflammatory mediators. J. Nutr. Biochem. 2016, 28, 103-113. [CrossRef]

76. Montrose, D.C.; Horelik, N.A.; Madigan, J.P.; Stoner, G.D.; Wang, L.S.; Bruno, R.S.; Park, H.J.; Giardina, C.; Rosenberg, D.W. Anti-inflammatory effects of freeze-dried black raspberry powder in ulcerative colitis. Carcinogenesis 2011, 32, 343-350. [CrossRef]

77. Piberger, H.; Oehme, A.; Hofmann, C.; Dreiseitel, A.; Sand, P.G.; Obermeier, F.; Schoelmerich, J.; Schreier, P.; Krammer, G.; Rogler, G. Bilberries and their anthocyanins ameliorate experimental colitis. Mol. Nutr. Food Res. 2011, 55, 1724-1729. [CrossRef]

78. Wang, L.S.; Kuo, C.T.; Stoner, K.; Yearsley, M.; Oshima, K.; Yu, J.; Huang, T.H.; Rosenberg, D.; Peiffer, D.; Stoner, G.; et al. Dietary black raspberries modulate DNA methylation in dextran sodium sulfate (DSS)-induced ulcerative colitis. Carcinogenesis 2013, 34, 2842-2850. [CrossRef]

79. Xiao, X.; Kim, J.; Sun, Q.; Kim, D.; Park, C.S.; Lu, T.S.; Park, Y. Preventive effects of cranberry products on experimental colitis induced by dextran sulphate sodium in mice. Food Chem. 2015, 167, 438-446. [CrossRef]

80. Anhê, F.F.; Roy, D.; Pilon, G.; Dudonné, S.; Matamoros, S.; Varin, T.V.; Garofalo, C.; Moine, Q.; Desjardins, Y.; Levy, E.; et al. A polyphenol-rich cranberry extract protects from diet-induced obesity, insulin resistance and intestinal inflammation in association with increased Akkermansia spp. population in the gut microbiota of mice. Gut 2015, 64, 872-883. [CrossRef]

81. Cui, X.; Jin, Y.; Hofseth, A.B.; Pena, E.; Habiger, J.; Chumanevich, A.; Poudyal, D.; Nagarkatti, M.; Nagarkatti, P.S.; Singh, U.P.; et al. Resveratrol suppresses colitis and colon cancer associated with colitis. Cancer Prev. Res. 2010, 3, 549-559. [CrossRef]

82. Sánchez-Fidalgo, S.; Cárdeno, A.; Villegas, I.; Talero, E.; Alarcón, C. Dietary supplementation of resveratrol attenuates chronic colonic inflammation in mice. Eur. J. Pharmacol. 2010, 633, 78-84. [CrossRef] [PubMed]

83. Singh, U.P.; Singh, N.P.; Singh, B.; Hofseth, L.J.; Price, R.L.; Nagarkatti, M.; Nagarkatti, P.S. Resveratrol (trans-3,5,4'-trihydroxystilbene) induces silent mating type information regulation-1 and down-regulates nuclear transcription factor- $\mathrm{kB}$ activation to abrogate dextran sulfate sodium-induced colitis. J. Pharmacol. Exp. Ther. 2010, 332, 829-839. [CrossRef] [PubMed]

84. Wagnerova, A.; Babickova, J.; Liptak, R.; Vlkova, B.; Celec, P.; Gardlik, R. Sex differences in the effect of resveratrol on DSS-induced colitis in mice. Gastroenterol. Res. Pract. 2017, 2017, 8051870. [CrossRef]

85. Yao, J.; Wang, J.Y.; Liu, L.; Li, Y.-X.; Xun, A.-Y.; Zeng, W.-S.; Jia, C.-H.; Wei, X.-X.; Feng, J.-L.; Zhao, L.; et al. Antioxidant effects of resveratrol on mice with DSS-induced ulcerative colitis. Arch. Med. Res. 2010, 41, 288-294. [CrossRef] [PubMed]

86. Larrosa, M.; Tomé-Carneiro, J.; Yáñez-Gascón, M.J.; Alcántara, D.; Selma, M.V.; Beltrán, D.; Garcia-Conesa, M.T.; Urbán, C.; Lucas, R.; Tomás-Barberán, F.A.; et al. Preventive oral treatment with resveratrol pro-prodrugs drastically reduce colon inflammation in rodents. J. Med. Chem. 2010, 53, 7365-7376. [CrossRef] [PubMed]

87. Youn, J.; Lee, J.-S.; Na, H.-K.; Kundu, J.K.; Dong, Z. Resveratrol and piceatannol inhibit iNOS expression and NF- $\mathrm{KB}$ activation in dextran sulfate sodium-induced mouse colitis. Nutr. Cancer 2009, 61, 847-854. [CrossRef] [PubMed]

88. Altamemi, I.; Murphy, E.A.; Catroppo, J.F.; Zumbrun, E.E.; Zhang, J.; McClellan, J.L.; Singh, U.P.; Nagarkatti, P.S.; Nagarkatti, M. Role of microRNAs in resveratrol-mediated mitigation of colitis-associated tumorigenesis in ApcMin/+ mice. J. Pharmacol. Exp. Ther. 2014, 350, 99-109. [CrossRef] [PubMed]

89. Singh, U.P.; Singh, N.P.; Singh, B.; Hofseth, L.J.; Taub, D.D.; Price, R.L.; Nagarkatti, P.S.; Nagarkatti, M. Role of resveratrol-induced $\mathrm{CD}_{11} \mathrm{~b}^{+} \mathrm{Gr}-1^{+}$myeloid derived sup-pressor cells (MDSCs) in the reduction of CXCR3 ${ }^{+}$ T cells and amelioration of chronic colitis in IL-10(-/-) mice. Brain Behav. Immun. 2012, 26, 72-82. [CrossRef]

90. Osman, N.; Adawi, D.; Ahrné, S.; Jeppsson, B.; Molin, G. Probiotics and blueberry attenuate the severity of dextran sulfate sodium (DSS)-induced colitis. Digest. Dis. Sci. 2008, 53, 2464-2473. [CrossRef] 
91. Abdallah, D.M.; Ismael, N.R. Resveratrol abrogates adhesion molecules and protects against TNBS-induced ulcerative colitis in rats. Can. J. Physiol. Pharmacol. 2011, 89, 811-818.

92. Lozano-Pérez, A.A.; Rodriguez-Nogales, A.; Ortiz-Cullera, V.; Algieri, F.; Zorrilla, P.; Rodríguez-Cabezas, M.E.; Mesa, N.G.; Utrilla, M.P.; De Matteis, L.; Mesa, J.G.; et al. Silk fibroin nanoparticles constitute a vector for controlled release of resveratrol in an experimental model of inflammatory bowel disease in rats. Int. J. Nanomed. 2014, 9, 4507-4520.

93. Martín, A.R.; Villegas, I.; La Casa, C.; De La Lastra, A. Resveratrol, a polyphenol found in grapes, suppresses oxidative damage and stimulates apoptosis during early colonic inflammation in rats. Biochem. Pharmacol. 2004, 67, 1399-1410. [PubMed]

94. Martín, A.R.; Villegas, I.; Sánchez-Hidalgo, M.; Alarcón, C. The effects of resveratrol, a phytoalexin derived from red wines, on chronic inflammation induced in an experimentally induced colitis model. Br. J. Pharmacol. 2006, 147, 873-885. [CrossRef] [PubMed]

95. Yildiz, G.; Yildiz, Y.; Ulutas, P.A.; Yaylali, A.; Ural, M. Resveratrol pretreatment ameliorates TNBS colitis in rats. Recent Pat. Endocr. Metab. Immune Drug Discov. 2015, 9, 134-140. [CrossRef]

96. Arslan, A.; Ozcicek, F.; Cimen, F.K.; Altuner, D.; Yarali, O.; Kurt, N.; Tumkaya, L.; Ozturk, C.; Suleyman, H. Protective effect of resveratrol against methotrexate- induced oxidative stress in the small intestinal tissues of rats. Int. J. Clin. Exp. Med. 2015, 8, 10491-10500. [PubMed]

97. Abdin, A.A. Targeting sphingosine kinase 1 (SphK1) and apoptosis by colon-specific delivery formula of resveratrol in treatment of experimental ulcerative colitis in rats. Eur. J. Pharmacol. 2013, 718, 145-153. [CrossRef] [PubMed]

98. Larrosa, M.; Yañéz-Gascón, M.J.; Selma, M.V.; González-Sarrías, A.; Toti, S.; Cerón, J.; Tomás-Barberán, F.A.; Dolara, P.; Espín, J.C. Effect of a low dose of dietary resveratrol on colon microbiota, inflammation and tissue damage in a DSS-induced colitis rat model. J. Agric. Food Chem. 2009, 57, 2211-2220. [CrossRef]

99. Rahal, K.; Schmiedlin-Ren, P.; Adler, J.; Dhanani, M.; Sultani, V.; Rittershaus, A.C.; Reingold, L.; Zhu, J.; McKenna, B.J.; Christman, G.M.; et al. Resveratrol has antiinflammatory and antifibrotic effects in the peptidoglycan-polysaccharide rat model of Crohn's disease. Inflamm. Bowel Dis. 2012, 18, 613-623. [CrossRef]

100. Biedermann, L.; Mwinyi, J.; Scharl, M.; Frei, P.; Zeitz, J.; Kullak-Ublick, G.A.; Vavricka, S.R.; Fried, M.; Weber, A.; Humpf, H.U.; et al. Bilberry ingestion improves disease activity in mild to moderate ulcerative colitis-An open pilot study. J. Crohns Colitis 2013, 7, 271-279. [CrossRef]

101. Samsami-Kor, M.; Daryani, N.E.; Asl, P.R.; Hekmatdoost, A. Anti-inflammatory effects of resveratrol in patients with ulcerative colitis: A randomized, double-blind, placebo-controlled pilot study. Arch. Med. Res. 2015, 46, 280-285. [CrossRef]

102. Samsami-Kor, M.; Daryani, N.E.; Asl, P.R.; Hekmatdoost, A. Resveratrol supplementation and oxidative/anti-oxidative status in patients with ulcerative colitis: A randomized, double-blind, placebo-controlled pilot study. Arch. Med. Res. 2016, 47, 304-309. [CrossRef] [PubMed] 